\title{
Hepatitis B DNA Positive
}

National Cancer Institute

\section{Source}

National Cancer Institute. Hepatitis B DNA Positive. NCI Thesaurus. Code C162043.

An indication that hepatitis B DNA has been detected in a sample. 